\section{(6) OPEN ACCESS}

\title{
Interaction between tumour-infiltrating $B$ cells and $T$ cells controls the progression of hepatocellular carcinoma
}

\author{
Marta Garnelo, ${ }^{1}$ Alex Tan, ${ }^{1}$ Zhisheng Her, ${ }^{2}$ Joe Yeong, ${ }^{1,3}$ Chun Jye Lim, ${ }^{4}$ \\ Jinmiao Chen, ${ }^{1}$ Kiat Hon Lim, ${ }^{3}$ Achim Weber, ${ }_{1}^{5}$ Pierce Chow, ${ }^{6,7,13}$ \\ Alexander Chung, ${ }^{6,7}$ London Lucien PJ Ooi, ${ }_{11}^{6,7,13}$ Han Chong Toh, ${ }^{6}$ \\ Mathias Heikenwalder ${ }_{1,9}^{8,9}$ Irene $\mathrm{OL} \mathrm{Ng}{ }_{1}^{10,11}$ Alessandra Nardin, ${ }^{1}$ Qingfeng Chen, ${ }^{2,6}$ \\ Jean-Pierre Abastado, ${ }^{1,12}$ Valerie Chew ${ }^{1,4,13}$
}

- Additional material is published online only. To view please visit the journal online (http://dx.doi.org/10.1136/ gutjnl-2015-310814).

For numbered affiliations see end of article.

\section{Correspondence to} Dr Valerie Chew, SingHealth Translational Immunology and Inflammation Centre (STIIC), Singapore Health Services Pte Ltd, 20 College Road, the Academia, Level 8 Discovery Tower, Singapore 169856, Singapore;

Valerie.chew.s.p@singhealth. com.sg

MG and AT contributed equally.

Received 28 September 2015 Revised 12 October 2015 Accepted 14 October 2015 Published Online First 15 December 2015
CrossMark

\begin{tabular}{l} 
To cite: Garnelo M, Tan A, \\
Her Z, et al. Gut \\
2017;66:342-351. \\
\hline
\end{tabular}

\section{ABSTRACT}

Objective The nature of the tumour-infiltrating leucocytes (TILs) is known to impact clinical outcome in carcinomas, including hepatocellular carcinoma (HCC). However, the role of tumour-infiltrating B cells (TIBs) remains controversial. Here, we investigate the impact of TIBs and their interaction with T cells on HCC patient prognosis.

Design Tissue samples were obtained from 112 patients with HCC from Singapore, Hong Kong and Zurich and analysed using immunohistochemistry and immunofluorescence. RNA expression of CD19, CD8A, IFNG was analysed using quantitative PCR. The phenotype of freshly isolated TILs was analysed using flow cytometry. A mouse model depleted of mature B cells was used for functional study.

Results Tumour-infiltrating T cells and B cells were observed in close contact with each other and their densities are correlated with superior survival in patients with HCC. Furthermore, the density of TIBs was correlated with an enhanced expression of granzyme B and IFN- $\gamma$, as well as with reduced tumour viability defined by low expression of Ki-67, and an enhanced expression of activated caspase-3 on tumour cells. CD27 and CD40 costimulatory molecules and TILs expressing activation marker CD38 in the tumour were also correlated with patient survival. Mice depleted of mature B cells and transplanted with murine hepatoma cells showed reduced tumour control and decreased local T cell activation, further indicating the important role of $B$ cells.

Conclusions The close proximity of tumour-infiltrating $T$ cells and $B$ cells indicates a functional interaction between them that is linked to an enhanced local immune activation and contributes to better prognosis for patients with HCC.

\section{INTRODUCTION}

Hepatocellular carcinoma (HCC) is the sixth most common cancer, but the second leading cause of death by cancer worldwide. ${ }^{1}$ The link between inflammation due to hepatitis virus infection or alcoholism and HCC tumorigenesis is well known, ${ }^{2}$ but the role of the immune response in cancer progression or prognosis requires further elucidation.

\section{Significance of this study}

What is already known on this subject?

- We have previously shown that the nature of tumour-infiltrating leucocytes has an impact on hepatocellular carcinoma (HCC) patient survival.

- Multiple costimulatory molecules involved in T cell-B cell interaction have been implicated in cancer prognosis.

- The role of tumour-infiltrating B cells (TIBs), however, remains controversial with several studies reporting contradictory findings.

\section{What are the new findings?}

- We show that the density of TIBs correlates with an enhanced expression of granzyme B and IFN- $\gamma$ as well as with reduced viability of tumour cells.

- We demonstrate the densities of T cells and B cells that are in close proximity to each other, costimulatory molecules CD27 and CD40 and activation marker CD38, all indicative of local immune activation were associated with better survival in a total of 112 patients from Singapore, Hong Kong and Zurich, that is, irrespective of patient ethnicity and disease aetiology.

- We use a murine model depleted of mature B cells and transplanted with murine hepatoma cell lines to demonstrate the critical role of $B$ cell in tumour control and local T cell activation.

\section{How might it impact on clinical practice in} the foreseeable future?

- Improved understanding of the importance of $T$ cell-B cell interaction, the costimulatory molecules involved and the resulting activation of local immune response in HCC progression.

- Providing evidence supporting clinical development of agonists targeting costimulatory molecules for cancer immunotherapy. 
Tumour-infiltrating T cells, especially $\mathrm{CD} 8^{+} \mathrm{T}$ cells, have been shown to play a critical role in controlling tumour progression. ${ }^{3}$ Studies in many human cancers, including HCC, demonstrated a positive correlation between the density of $\mathrm{T}$ cells and better patient prognosis. ${ }^{4}$ On the other hand, the involvement of $\mathrm{B}$ cells in cancer development and progression is rather controversial. Previous findings from a diethylnitrosamine-induced liver cancer mouse model showed that $\mathrm{T}$ cells and $\mathrm{B}$ cells are important in suppressing tumour development and progression. ${ }^{5}$ Several B cell activation genes were reported to be downregulated in patients with HCC with poor prognosis suggesting their protective roles in tumour progression. ${ }^{5}$ Others, however, found that a special subset of B cells defined as regulatory B cells (Bregs) with $\mathrm{CD} 19^{+} \mathrm{CD} 24^{\mathrm{hi}} \mathrm{CD} 38^{\mathrm{hi}}$ phenotype was enriched in the tumour microenvironment and was associated with progression of various cancers, including HCC. ${ }^{67}$

The interaction between $\mathrm{T}$ cells and $\mathrm{B}$ cells is known to be critical in the activation of local immune response in several inflammatory conditions, including cancer. ${ }^{8}$ Multiple costimulatory and coinhibitory molecules that are expressed on $\mathrm{T}$ cells have been the recent targets of a new generation of immunotherapies, such as anti-CTLA-4, anti-PD-1/PD-L1 or anti-OX40 antibodies, which aim to enhance the local antitumour immune response either through blocking coinhibitory checkpoint receptors or activating costimulatory receptors expressed on tumourinfiltrating T cells. ${ }^{9}$ The balance of these molecules/receptors has been shown to be paramount in eliciting efficient antitumour immune response, supporting the basis of combinatorial strategy in immunotherapy. ${ }^{10}$

We here present an extensive retrospective study on the role of $\mathrm{T}$ cells and $\mathrm{B}$ cells from a total of 112 patients with HCC from Singapore, Hong Kong and Zurich, that is, with different ethnicities as well as disease aetiologies. By investigating the archived tissues from patients with HCC, we found that the densities of both $\mathrm{T}$ cells and $\mathrm{B}$ cells are associated with better patient survival and decreased tumour aggressiveness. The phenotype of both tumour-infiltrating $\mathrm{T}$ and $\mathrm{B}$ cells suggests that they acquire an activated phenotype as a result of their close proximity and interaction. A mouse model depleted of mature B cells further demonstrated the key role of B cells in controlling tumour progression and local $\mathrm{T}$ cell activation.

\section{MATERIALS AND METHODS \\ Patients}

One hundred and twelve formalin-fixed paraffin-embedded (FFPE) patient tissue samples from resected HCC were obtained from the National Cancer Centre (NCC), Singapore $(n=40)$; the Queen Mary Hospital, Hong Kong $(n=45)$ and the University Hospital Zurich, Switzerland $(n=27)$. The tissues were used for immunohistochemistry (IHC) or immunofluorescence (IF) labelling. Among these, 81 RNA samples were also obtained for gene expression analysis. All samples were obtained with ethics committee approval from patients who underwent curative resection from 1991 to 2009. A table comparing patient characteristics from different cohorts is listed in online supplementary table S1. Immune cells were freshly isolated from HCC tumour, adjacent non-tumour tissues as well as peripheral blood mononuclear cells (PBMCs) from seven patients with HCC and were analysed using flow cytometry. Patient consent was obtained from each case with institutional review board (IRB) approval.

\section{Immunohistochemistry and immunofluorescence}

IHC and IF staining were performed on FFPE tissue samples as described previously. ${ }^{11}$ The antibodies used are listed in online supplementary table S2. IF images were captured using Olympus FluoView FV1000 confocal microscope with 4',6-diamidino-2-phenylindole (DAPI) as the nuclear marker. IHC images were obtained with an Olympus DP20 camera attached to a CX31 microscope. Multiplex tissue fluorescence staining was performed with Opal staining system and images were acquired using Mantra platform (Perkin Elmer). ${ }^{12-14}$

Quantification of positively stained cells was performed using ImagePro Software and verified with manual counting from 5 to 10 random fields at $100 \times$ magnification. The mean number from all fields from each patient sample was taken and the density of cell of interest (number $/ \mathrm{mm}^{2}$ ) was calculated based on the area of each tumour field at $100 \times$ magnification measured as $1.27 \mathrm{~mm}^{2}$. The definitions of peritumour, intratumoral and non-tumour at the tumour margin are illustrated in online supplementary figure S1.

\section{Gene expression analysis}

Quantitative PCR (qPCR) assay was performed on a total of 81 mRNA samples as described previously. ${ }^{11}$ Briefly, primers were designed using Primer3 and qPCR assay was performed using iTaq SYBR Green Supermix with ROX (Bio-Rad Laboratories). Relative RNA expression of CD19, CD8A and IFNG was calculated by normalisation to the housekeeping gene beta-actin $(A C T B)$ using MxPro Software (Stratagene). The primers used were as follows: CD19 primers: FW' $^{\prime}$ TCCTTCT CCAACGCTGAGTC， RV' GCTCAGGAAGTCCATTGTCC; CD8A primers: $\mathrm{FW}^{\prime}$ CCCTTTACTGCAACCACAGG, RV' GTCTCCCGATTTGACCACAG; IFNG primers: $\mathrm{FW}^{\prime}$ ATGCAGGTCATTCAGATGTAGC, RV' TGTCACTCTCCTCT TTCCAATTC and ACTB primers: FW' $^{\prime}$ CCAACCGCGA GAAGATGA, RV' TAGCACAGCCTGGATAGCAA.

\section{Flow cytometry}

PBMCs were isolated using standard ficoll procedure and tumour dissociation was performed as previously described. ${ }^{15}$ The immune cells were stained with antibodies as listed in online supplementary table S2.

\section{Mice}

Male wild-type (WT) C57BL/6 mice at 6-7 weeks of age were used. To induce in vivo $\mathrm{B}$ cell depletion, one single dose of mouse anti-mouse CD20 (clone 5D2, isotype IgG2a, Genentech) or isotype-matched control $\mathrm{mAb}(100 \mu \mathrm{g})$ was injected in $200 \mu \mathrm{L}$ phosphate buffered saline (PBS) through lateral tail veins. ${ }^{16} \mathrm{~A}$ single dose of this depleting antibody ensures the B cell depletion from Day 7 to as long as 57 days post-injection. ${ }^{16}$ Sixteen days after, $3 \times 10^{6}$ Hepa1-6 hepatoma cell lines were transplanted into both flanks of the mice. Tumour growth was monitored using calliper on Days 17, 19, 23, 26 and 30 before the mice were sacrificed on Day 31. Tumours and spleens were harvested for analysis of tumour-infiltrating leucocytes (TILs) using flow cytometry. Antibodies used include CD45, CD3 CD8, CD19, granzyme B (GZB), PD-1 (eBiosciences), CD4, NK1.1, CD69 and IFN- $\gamma$ (BioLegend). Animal care and all experimental procedures were approved by the Institutional Animal Care and Use Committee from Biological Resource Centre, A*STAR, Singapore.

\section{Statistical analysis}

Kaplan-Meier univariate survival analysis was performed using classification as 'low' or 'high' according to the median densities of cells of interest and $\mathrm{p}$ values are reported using log-rank (Mantel-Cox) test with HR and 95\%CI. For correlation 
analyses, $\mathrm{p}$ values and correlation coefficients ( $\mathrm{r}$ ) were calculated using the Pearson's correlation test. Both tests were performed using GraphPad Prism V.6.03 (GraphPad Software).

Multivariate analysis by Cox proportional hazards model was used to examine the predictive value of densities of tumourinfiltrating $\mathrm{CD}^{+} \mathrm{T}$ cells and $\mathrm{CD} 20^{+} \mathrm{B}$ cells in the context of other clinical variables. The variables were chosen with a stepwise approach to calculate Akaike's information criteria (AIC), starting from a full model comprising CD3, CD20, grade, stage, age and pairwise interactions. At each iteration step, variables were removed or added to the current model and AIC were calculated for the new models until the model being tested showed a lower AIC. The final model we reached is as follows: coxph (formula $=$ Surv(survival, death) $\sim \mathrm{CD} 3+\mathrm{CD} 20+$ grade + as. factor(stage) + age +CD3:CD20+CD3: grade +CD20:age + grade: age + as.factor(stage):age). Stage is considered as a factor where stage $\mathrm{I}$ is used as the baseline.

\section{RESULTS}

The density of tumour-infiltrating B cells correlates with that of the tumour-infiltrating $T$ cells

Given the controversial role of B cells in tumour progression, especially in HCC, we investigated whether tumour-infiltrating B cells (TIBs) could play a role in HCC progression. First, we performed IF staining for $\mathrm{CD} 20^{+} \mathrm{B}$ cells together with $\mathrm{CD} 3^{+} \mathrm{T}$ cells in tumour tissue samples from patients with HCC. We observed that $\mathrm{CD} 20^{+} \mathrm{B}$ cells are in close proximity to $\mathrm{CD} 3^{+} \mathrm{T}$ cells forming either a small cluster (figure 1A) or, less frequently (one-third of the cases), a tertiary lymphoid-like structure with $\mathrm{T}$ cells and $\mathrm{B}$ cells organised in a feature resembling a germinal
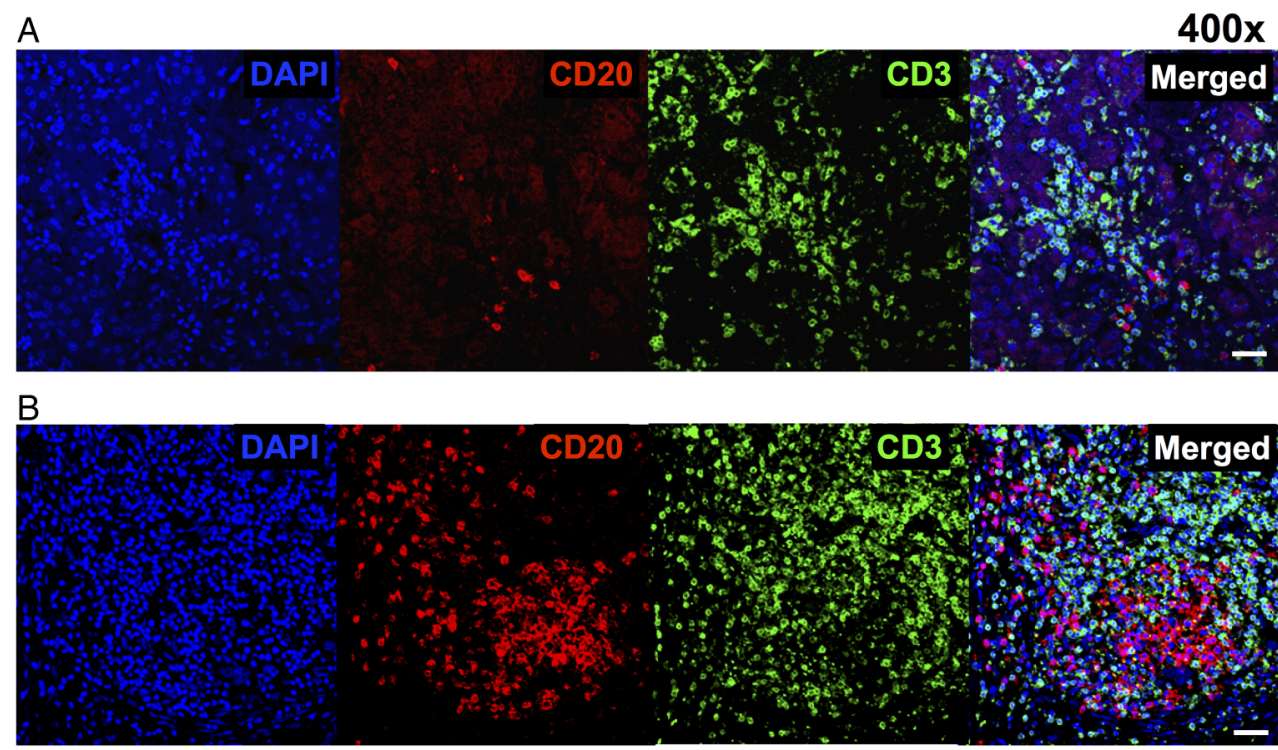

C
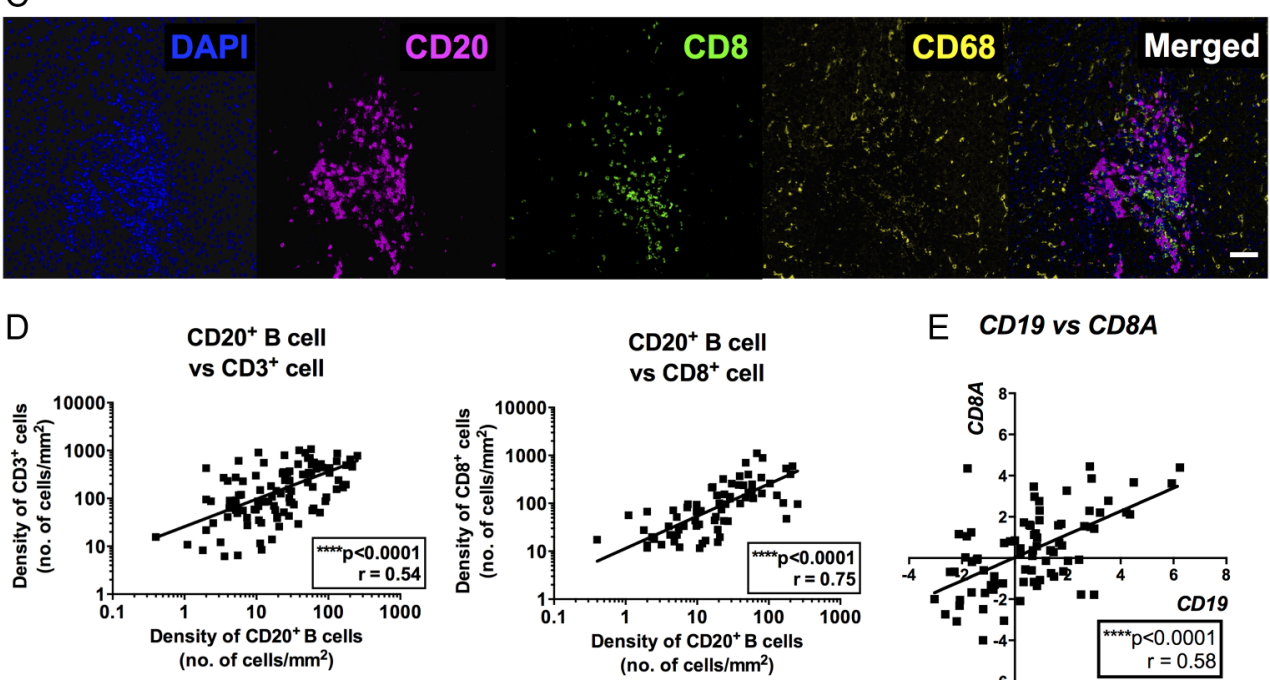

E CD19 vs CD8A

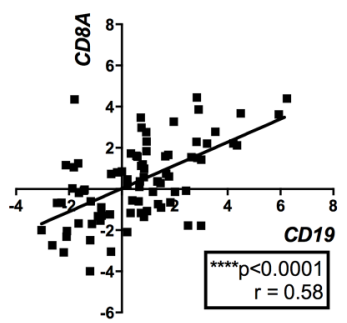

Figure 1 Tumour-infiltrating T and B cells are in close contact and their densities are correlated with each other within the hepatocellular carcinoma (HCC) microenvironment. Representative immunofluorescence images on CD20 (red), CD3 (green) and nuclear staining with DAPI (blue) showing (A) a small aggregate and (B) a tertiary lymphoid structure formed with T and B cells in HCC. $400 \times$ magnification. Bar=30 $\mu$ m. (C) Representative images from multiplex tissue fluorescence staining using Opal (Perkin Elmer) showing DAPI (blue), CD20 (magenta), CD8 (green) and CD68 (yellow). 200x magnification. Bar $=50 \mu \mathrm{m}$. (D) The density of tumour-infiltrating B cells (number of cells/mm²) is correlated with tumour-infiltrating $\mathrm{CD}^{+}(\mathrm{n}=103)$ and $\mathrm{CD}^{+}(\mathrm{n}=70)$ T cells. (E) Relative RNA expression of $C D 19$ (B cell marker) and CD8A (CD8 ${ }^{+}$T cell marker) normalised to the housekeeping gene $A C T B$ is correlated with each other $(n=81)$. Graphs show p value against Pearson correlation coefficients $r$. $* * * * p<0.0001$. 
centre (figure 1B). In almost all cases, $\mathrm{T}$ cells and $\mathrm{B}$ cells are in close proximity or even in contact with one another. Notably, such structures appear within the tumour bed, as well as at the infiltrating margin of tumours. About $70 \%$ of the bigger clusters resembling tertiary lymphoid structures appear at the infiltrating margin of tumours, which are also considered as the intratumoral regions. A typical example showing strong B cell infiltration at the invasive margin and in the tumour bed is given in online supplementary figure S1. Importantly, such interaction is specific to $\mathrm{T}$ cells where multiplex tissue staining with Opal (Perkin Elmer) showed that CD $20^{+} \mathrm{B}$ cells form a cluster with $\mathrm{CD}^{+} \mathrm{T}$ cells while not with the $\mathrm{CD} 68^{+}$macrophages which are abundant in HCC tissues (figure 1C). Further IHC staining and quantification for CD20 and CD3 on tumour tissues from a total of 112 patients with HCC from Singapore, Hong Kong and Zurich demonstrated that, indeed, the density of $\mathrm{CD} 20^{+} \mathrm{B}$ cells closely correlates with the densities of both $\mathrm{CD}^{+}$and $\mathrm{CD}^{+} \mathrm{T}$ cells (see figure $1 \mathrm{D}$ and online supplementary figure S2A). A weak correlation was also observed between the densities of $\mathrm{CD} 20^{+} \mathrm{B}$ cells and $\mathrm{CD} 56^{+} \mathrm{NK}$ cells, but not with $\mathrm{CD} 8^{+}$macrophages (see online supplementary figure S2B). To further confirm these IHC data, we performed qPCR on RNA samples from a total of 81 patients with HCC and observed a striking correlation between CD19 (another marker for B cells) and CD8A gene expression in these tumour samples (figure 1E). Taken together, IHC and transcriptome analysis confirm that the density of TIBs correlates with T cell infiltration to HCC.

The density of TIBs correlates with T cell and NK cell activation and decreased tumour cell viability

We further investigated whether the intratumoral density of TIBs is associated with any particular phenotypes of TILs or tumour cells in microenvironment of HCC. First, we found that the density of TIBs correlates with the intratumoral density of GZB, an activation marker for both T cells and NK cells by IHC staining (figure 2A). Additionally, qPCR was performed on RNA samples from 75 patients with HCC and the correlation between CD19 and IFNG (another activation marker for T and NK cells) expression was also observed (figure 2B). Further double IHC staining on tissues and flow cytometry analysis on freshly isolated TILs demonstrated that T and NK cells are the major sources of GZB and IFN- $\gamma$ (see online supplementary figure S3A, B).
Figure 2 The density of tumour-infiltrating B cells (TIBs) is correlated with an enhanced T and NK cell activation and reduced tumour cell viability. (A) The density of $C D 20^{+}$TIBs is correlated with the density of total granzyme $B(G Z B)^{+}$tumour-infiltrating leucocytes $(n=50)$. (B) RNA expression of CD19 correlates with IFNG activation marker for $\mathrm{T}$ and NK cells $(n=75)$. (C) Graphs showing correlation of densities of $\mathrm{CD} 20^{+}$TIBs with $\mathrm{CD}^{+} 6^{+} \mathrm{GZB}^{+}$cells (left) and $\mathrm{CD}^{+} \mathrm{GZB}^{+}$ cells (right). (D) The density of $\mathrm{CD} 20^{+}$ TIBs negatively correlated with Caspase- $3^{+}$tumour cells $(n=54)$ and positively with $\mathrm{Ki}-67^{+}$tumour cells $(n=40)$. Graphs show $p$ value against Pearson correlation coefficients $r$. ${ }^{*} p<0.05 ;{ }^{* *} p<0.01 ;{ }^{* * * *} p<0.0001$
A
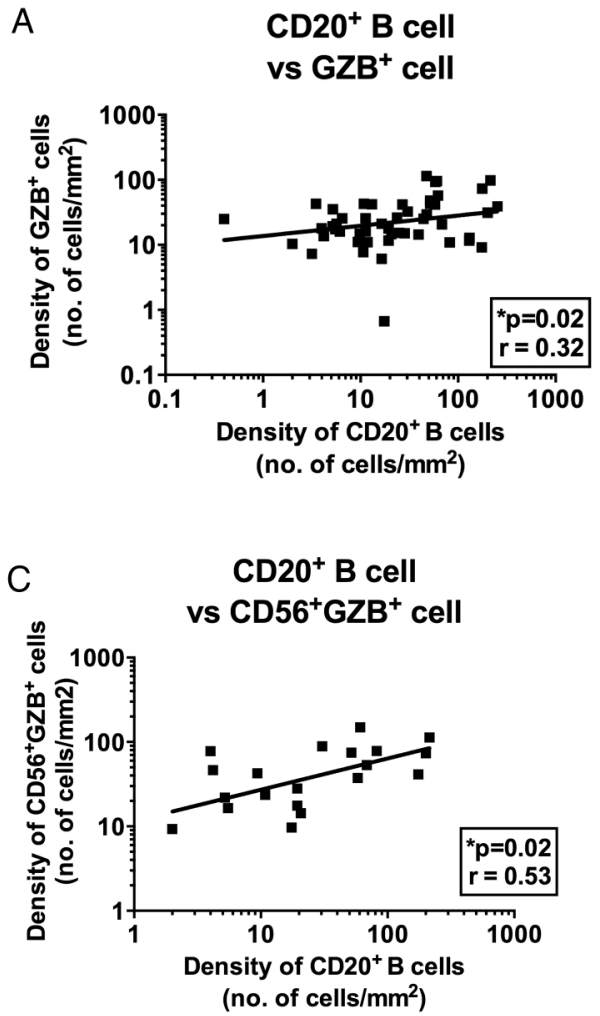

D

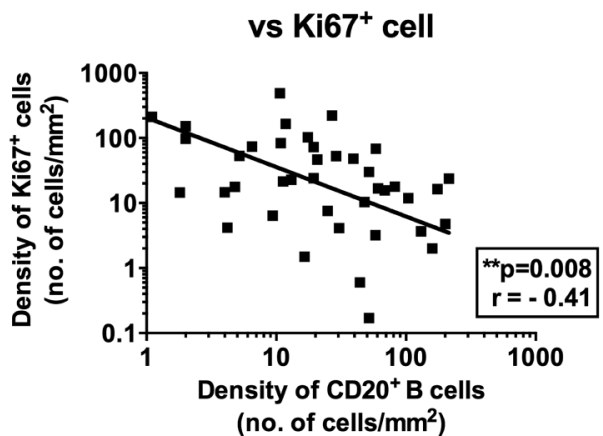

$\mathrm{B}$

\section{CD19 vs IFNG}
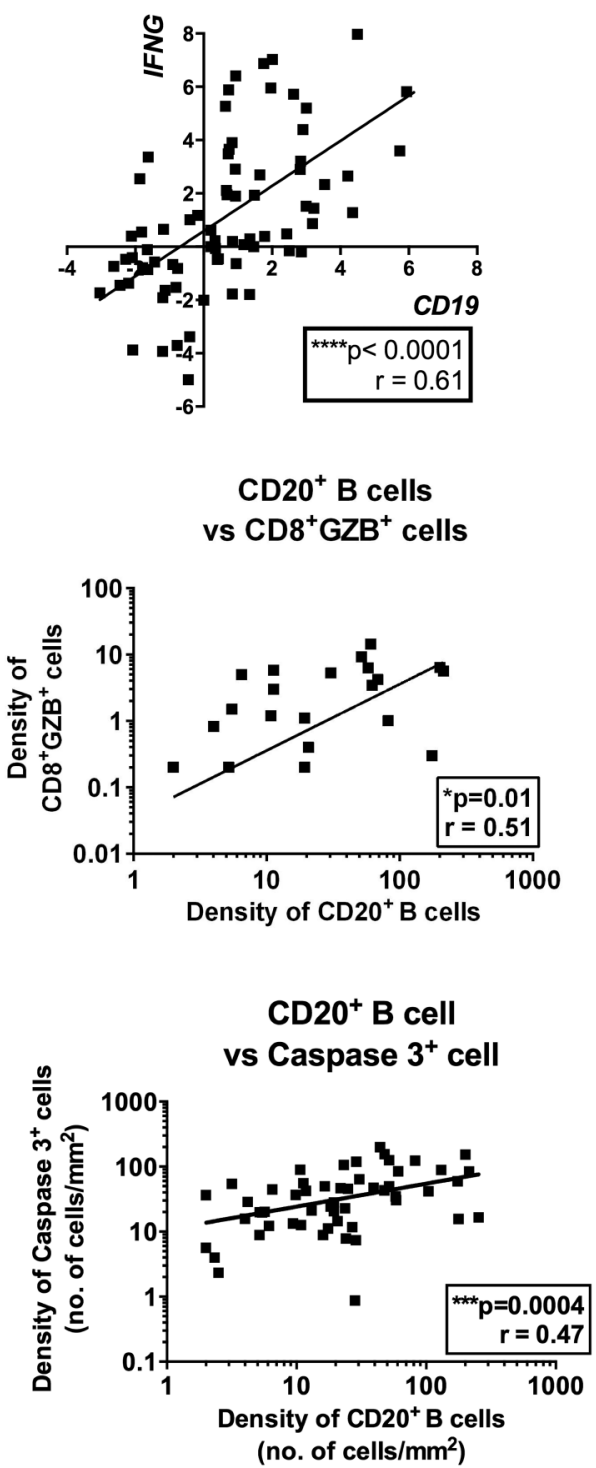


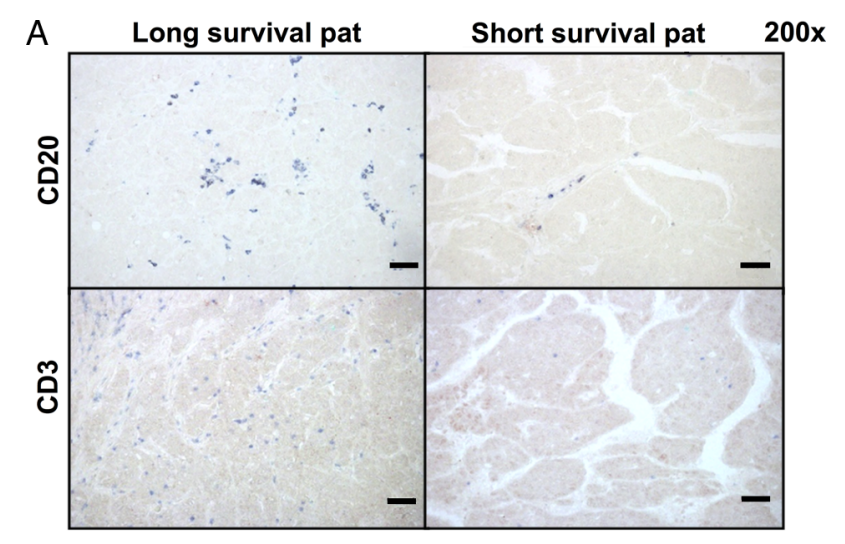

B
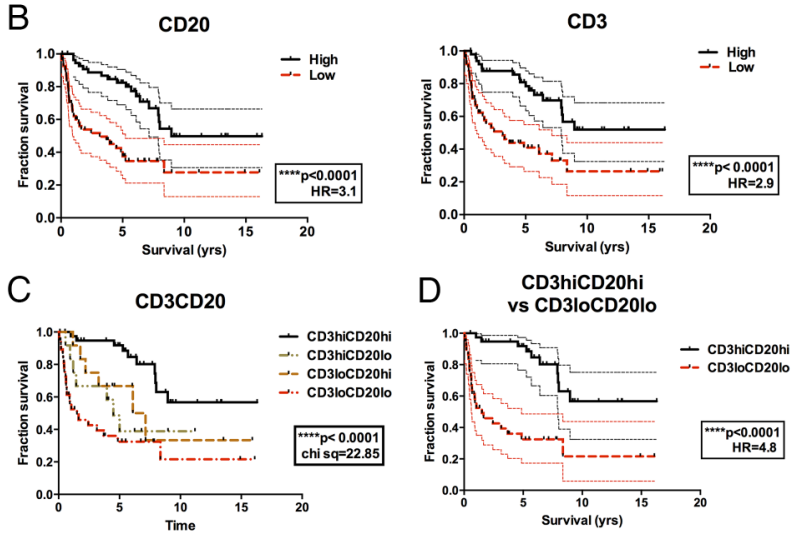

Figure 3 Densities of tumour-infiltrating $T$ and $B$ cells are associated with superior hepatocellular carcinoma (HCC) patient survival. (A) Representative immunohistochemistry images showing higher densities of $\mathrm{CD}_{20} \mathrm{~B}^{+} \mathrm{B}$ and $\mathrm{CD}^{+} \mathrm{T}$ cells (in blue) from long versus short survival patient. Survival profile is based on either $\geq$ (long) or $<$ (short) median survival of 4.5 years. Bar $=50 \mu \mathrm{m}$. (B) Kaplan-Meier (KM) analysis graph showing densities of $C_{2} 20^{+} B(n=112)$ and $C D 3^{+} T(n=103)$ cells are associated with favourable HCC patient survival. (C) KM analysis graph showing the patient survival profile by combining the densities of both CD20 ${ }^{+}$B and $C^{+} 3^{+}$T cells. CD ${ }^{\text {hi }} C D 20^{\text {hi }}(n=39), C^{\text {hi }}{ }^{\text {CD20 }}{ }^{\text {lo }}(n=12)$, $\mathrm{CD} 3{ }^{\text {lo }} \mathrm{CD} 20^{\mathrm{hi}}(\mathrm{n}=13)$ and $\mathrm{CD} 3{ }^{\mathrm{lo}} \mathrm{CD} 20^{\mathrm{lo}}(\mathrm{n}=38)$. (D) KM analysis showing survival profiles of patients with $C D 3^{\text {hi }} C D 20^{\text {hi }}(n=39)$ versus $\mathrm{CD} 3{ }^{\text {lo }} \mathrm{CD} 20^{\text {lo }}(\mathrm{n}=38)$. lo and hi indicate $\geq$ (low) or $<$ (high) median densities of $C D 20^{+} B$ cells (16 cells $/ \mathrm{mm}^{2}$ of tumour area) and $\mathrm{CD}^{+}$ T cells $\left(95 / \mathrm{mm}^{2}\right.$ of tumour area). Graphs show $p=\log$-rank test $p$ value. ${ }^{* * *} \mathrm{p}<0.001 ;{ }^{* * * *} \mathrm{p}<0.0001$.
Table 2 Multivariate survival analysis by Cox regression model

\begin{tabular}{|c|c|c|}
\hline Variables & HR $(95 \% \mathrm{Cl})$ & $\mathrm{p}$ Value \\
\hline $\mathrm{CD}^{+} \mathrm{T}$ cell density & 1.0086 (1.0010 to 1.0160$)$ & $0.0213^{*}$ \\
\hline $\mathrm{CD} 20^{+} \mathrm{B}$ cell density & $1.0799(1.0030$ to 1.1630$)$ & $0.0424^{*}$ \\
\hline Grade & 924 (54.42 to 15700$)$ & $2.30 \mathrm{e}^{-06 * * *}$ \\
\hline as.factor (stage) II & 25.3168 (0.1016 to 6308$)$ & $0.2511^{\mathrm{ns}}$ \\
\hline as.factor (stage) III & $0.1002\left(7.192 \mathrm{e}^{-04}\right.$ to 13.97$)$ & $0.3611^{\mathrm{ns}}$ \\
\hline as.factor (stage) IV & $1411\left(3.160\right.$ to $\left.6.302 \mathrm{e}^{+05}\right)$ & $0.0198^{*}$ \\
\hline Age & $1.2322(1.092$ to 1.390$)$ & $6.80 \mathrm{e}^{-04 * * *}$ \\
\hline $\mathrm{CD} 3: \mathrm{CD} 20$ & 0.9999 (0.9999 to 1.000$)$ & $0.1795^{\mathrm{ns}}$ \\
\hline CD3:grade & $0.9946(0.9912$ to 0.9981$)$ & $0.0022^{* *}$ \\
\hline CD20:age & $0.9987(0.9975$ to 0.9998$)$ & $0.0256^{*}$ \\
\hline Grade:age & $0.9238(0.8837$ to 0.9658$)$ & $0.0005^{* * *}$ \\
\hline as.factor (stage) II:age & $0.9810(0.8997$ to 1.0700$)$ & $0.6643^{\text {ns }}$ \\
\hline as.factor (stage) III:age & $1.0790(0.9977$ to 1.1670$)$ & $0.0571^{\mathrm{ns}}$ \\
\hline as.factor (stage) IV:age & $0.9498(0.8636$ to 1.0450$)$ & $0.2892^{\mathrm{ns}}$ \\
\hline
\end{tabular}

Indeed, the density of TIBs correlated with the densities of $\mathrm{CD}^{+}{ }^{+} \mathrm{T}$ cells and CD56 ${ }^{+} \mathrm{NK}$ cells that express GZB (figure 2C). Meanwhile, we also detected GZB expression by $\mathrm{CD} 68^{+}$macrophages in multiplex tissue fluorescence staining by Opal system (see online supplementary figure 3C). As both GZB and IFN- $\gamma$ represent activation markers for cytotoxic T and NK cells, the density of TIBs is correlated with the activation of both $\mathrm{CD}^{+} \mathrm{T}$ and $\mathrm{CD} 56^{+} \mathrm{NK}$ cells intratumorally and hence possibly leads to an enhanced local antitumour immune response. To demonstrate that TIBs are indeed correlated with an enhanced antitumour immune response, we analysed the density of TIBs in the context of the tumour viability markers. We observed that the density of TIBs correlates with the density of apoptotic tumour cells measured as activated caspase-3-positive tumour cells (see figure 2D and online supplementary figure S4). Conversely, the density of TIBs negatively correlates with the density of proliferating tumour cells as identified by their expression of Ki-67 (figure 2D and online supplementary figure S4).

\section{The densities of tumour-infiltrating T cells and B cells are associated with superior HCC patient survival}

We previously demonstrated that the densities of tumourinfiltrating $\mathrm{CD}^{+}{ }^{+} \mathrm{T}$ cells and $\mathrm{CD} 56^{+} \mathrm{NK}$ cells are associated with

Table 1 Univariate analysis of various clinical parameters and densities of intratumoral $\mathrm{CD}_{2} \mathrm{O}^{+} \mathrm{B}$ cells and $\mathrm{CD} 3^{+} \mathrm{T}$ cells as predictors of patient survival

\begin{tabular}{|c|c|c|c|c|}
\hline Variables & Number (\%) & Median (range) & $\mathrm{HR}(95 \% \mathrm{Cl})$ & p Value \\
\hline Grade $(1+2 / 3+4)$ & $82 / 21(80 / 20)$ & NA & $0.4(0.1$ to 0.7$)$ & $0.0055^{* *}$ \\
\hline TNM stage $(I+I I / I I+I V)$ & $64 / 45(59 / 41)$ & NA & $0.4(0.2$ to 0.7$)$ & $0.0020^{* *}$ \\
\hline Tumour size, $\mathrm{cm}$ (<median/ $\geq$ median) & NA & $5(0.7-27)$ & $0.6(0.3$ to 1.0$)$ & $0.0702^{\mathrm{ns}}$ \\
\hline $\operatorname{AFP}(\mathrm{ng} / \mathrm{mL})(<$ median/ $\geq$ median $)$ & NA & $52(1->70700)$ & $0.8(0.5$ to 1.4$)$ & $0.4092^{\text {ns }}$ \\
\hline Age (<median/ $\geq$ median) & NA & $58(20-84)$ & $0.5(0.3$ to 0.8$)$ & $0.0106^{*}$ \\
\hline Viral status (non-infected/HepB+C) & $37 / 72(34 / 66)$ & NA & $1.1(0.6$ to 2.0$)$ & $0.8163^{\mathrm{ns}}$ \\
\hline Race (others/Chinese) & $26 / 83(24 / 76)$ & NA & $1.3(0.6$ to 2.6$)$ & $0.4985^{\mathrm{ns}}$ \\
\hline Gender (female/male) & $21 / 89(19 / 81)$ & NA & $0.7(0.3$ to 1.4$)$ & $0.2903^{\mathrm{ns}}$ \\
\hline $\mathrm{CD} 20^{+}$B cell density $(<$median $/ \geq$median $)$ & NA & $16(0.3-199)$ & $3.1(1.9$ to 6.0$)$ & $<0.0001 * * * *$ \\
\hline $\mathrm{CD}^{+} \mathrm{T}$ cell density (<median/ $\geq$ median) & NA & $95(5-840)$ & $2.9(1.7$ to 5.5$)$ & $<0.0001^{* * * *}$ \\
\hline
\end{tabular}

${ }^{*} p<0.0{ }^{* *} p<0.01{ }^{* * *} p<0.001{ }^{* * * *} p<0.0001$

AFP, alpha-fetoprotein; TNM, tumour, node, metastases. 
longer HCC patient survival. ${ }^{11}$ Given the above observation, we investigated the association between the densities of intratumoral $\mathrm{CD} 20^{+} \mathrm{B}$ cells and CD ${ }^{+}$T cells and HCC patient survival. IHC staining and quantification for CD20 and CD3 were performed as described above. The densities of both intratumoral CD20 ${ }^{+} \mathrm{B}$ cells and $\mathrm{CD}^{+} \mathrm{T}$ cells were associated with superior HCC patient survival (figure $3 \mathrm{~A}, \mathrm{~B}$ and table 1 ). Since CD20 ${ }^{+} \mathrm{B}$ cells are located in close proximity to $\mathrm{T}$ cells, we then investigated their influence on patient survival when their densities are taken into consideration together (figure 3C). We observed that patients with high intratumoral densities of both $\mathrm{CD} 20^{+} \mathrm{B}$ cells and $\mathrm{CD}^{+}$T cells had longer survival compared with those with low densities of both subsets (figure $3 \mathrm{D}$ vs figure $3 \mathrm{~B} ; \mathrm{HR}=4.8$ vs 3.1 and 2.9 for either $\mathrm{CD} 20^{+} \mathrm{B}$ cells or $\mathrm{CD}^{+} \mathrm{T}$ cells, respectively). The densities of intratumoral $\mathrm{CD}^{+}{ }^{+}$T cells and $\mathrm{CD} 20^{+} \mathrm{B}$ cells (TIBs) were both independent predictors of HCC patient survival as shown in the multivariate Cox regression analysis together with grade, stage and age (table 2). The interaction between CD3 and grade was significantly associated with survival, suggesting that the relationship between CD3 and survival varied between different grades. The interaction between CD20 and age is also significant, which suggests the relationship between CD20 and survival varied at different age (table 2). For instance, the effect of CD3 on survival is more profound in the group of patients with advanced grades ( 3 or 4 vs 1 or 2 ), while the effect of CD20 on survival is more profound in the group of patients with advanced age of more than 58 years old.

Costimulatory molecules CD27 and CD40 expressed on both $T$ cells and B cells correlate with patient survival

Based on the above observations, T and B cell proximity potentially reflects functional interaction. The interaction between
A

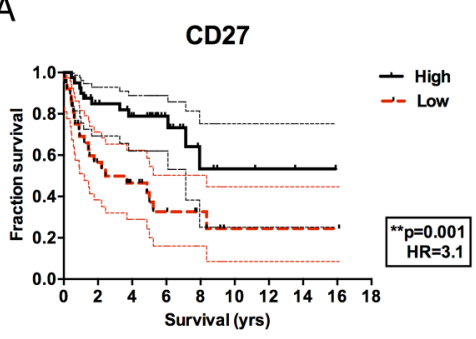

C

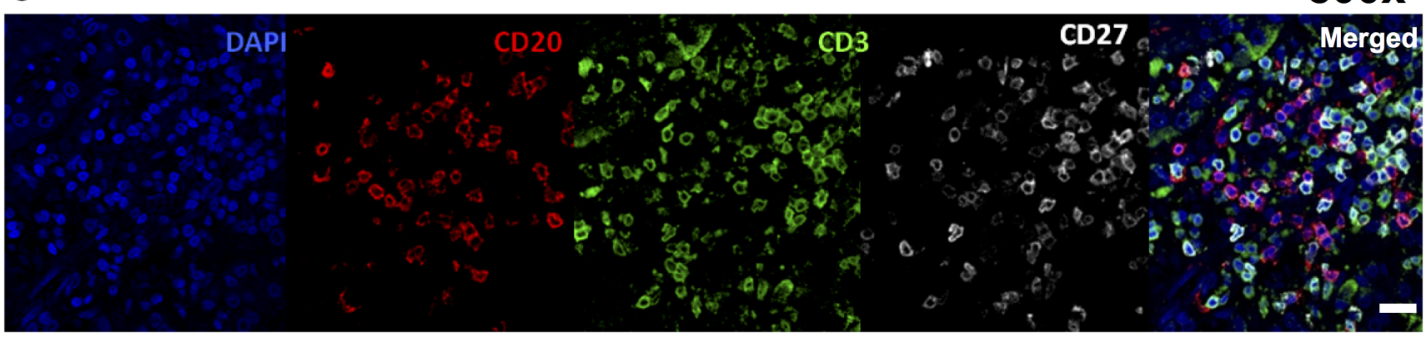

D

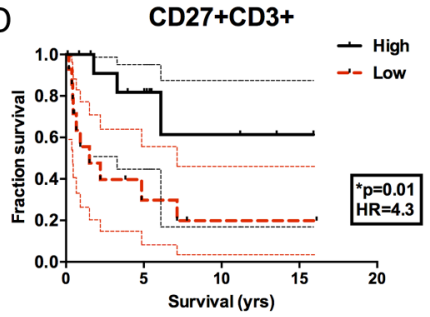

F
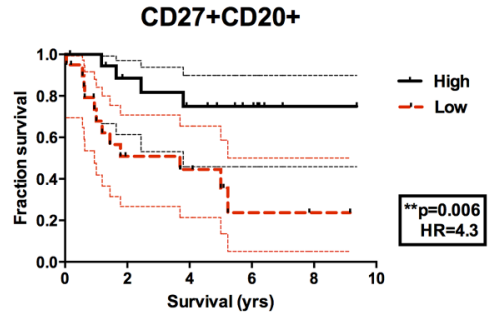

E

CD40 KM

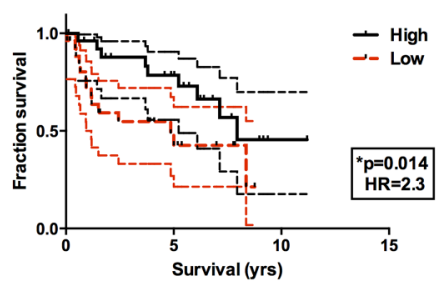

$800 x$

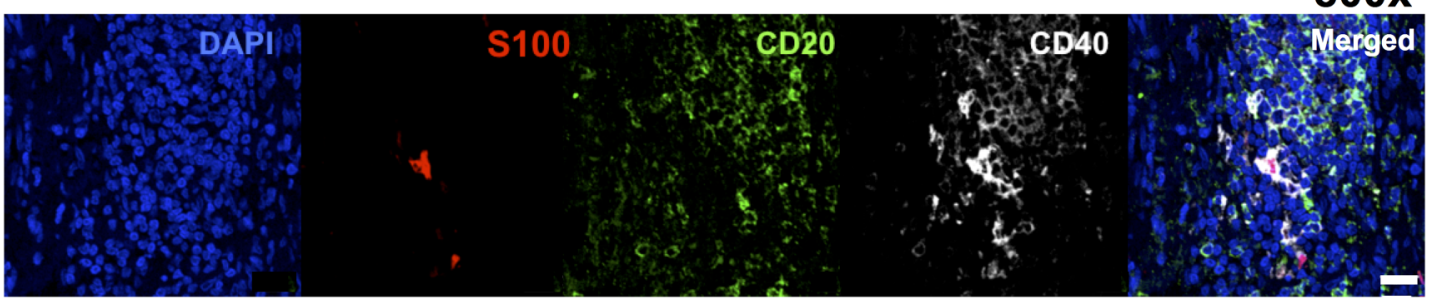

Figure 4 CD27 and CD40 costimulatory molecules are associated with superior hepatocellular carcinoma (HCC) patient survival. (A) Kaplan-Meier (KM) analysis graph showing the density of $\mathrm{CD} 27^{+}$tumour-infiltrating leucocytes (TILs) is associated with superior HCC patient survival. $\mathrm{n}=80$. (B) Representative immunohistochemistry images showing CD27 (red) with CD3 (blue) and CD20 (blue) at 200x magnification. Bar=30 $\mu$ m. (C) Representative immunofluorescence (IF) images at 800x magnification showing DAPI (blue), CD20 (red), CD3 (green), CD27 (white) and merged image on the far right. Bar $=20 \mu \mathrm{m}$. (D) KM analysis graphs showing that densities of $C D 27^{+} \mathrm{CD}^{+}($left, $n=28)$ and $C D 27^{+} \mathrm{CD} 20^{+}$(right, $\left.\mathrm{n}=39\right)$ are associated with superior patient survival. (E) KM analysis graph showing that the density of CD40+ ${ }^{+}$IILs is associated with superior HCC patient survival ( $n=54)$. (F) Representative IF images at 800x magnification showing DAPI (blue), S100 (red), CD20 (green), CD40 (white) and merged image on the far right. $B a r=20 \mu \mathrm{m}$. Graphs show $p=\log$-rank test $p$ value. ${ }^{*} p<0.05 ;{ }^{* *} p<0.01$. 
T cells and B cells could result in bidirectional T cell and B cell activation. Costimulatory molecules indicative of B cell activation such as CD27 could be an important indicator for such interaction/activation state. ${ }^{17}$ Indeed, the expression of CD27 on TILs within HCC determined by IHC analysis is positively associated with overall patient survival (figure 4A). Closer examination of $\mathrm{CD} 27^{+}$cells showed that both T cells and B cells can express CD27 in HCC (figure 4B, C). On average, 48\% of total $\mathrm{CD} 20^{+} \mathrm{B}$ cells (range, 1-90\%) and $64 \%$ of total CD3 ${ }^{+} \mathrm{T}$ cells (range, 4-98\%) express CD27. It was previously shown that CD27 is expressed on most T cells, including naive T cells, but it is only upregulated on activated B cells. ${ }^{18}$ This indicates that close to half of the TIBs are activated $\left(\mathrm{CD} 27^{+}\right)$. The majority of $\mathrm{CD} 27^{+}$population consists of $\mathrm{CD}^{+} \mathrm{T}$ cells (average of $59 \%$; range, $13-88 \%$ ), while $\mathrm{CD} 20^{+} \mathrm{B}$ cells make up $12 \%$ (range, $2-42 \%$ ) of the total $\mathrm{CD} 27^{+}$population. Importantly, the frequency of either $\mathrm{CD}^{+} \mathrm{T}$ cells or $\mathrm{CD} 20^{+} \mathrm{B}$ cells that express CD27 is positively associated with superior patient survival (figure 4D).

The above results suggest that the interaction between $\mathrm{B}$ and $\mathrm{T}$ cells is an important event leading to their activation and hence tumour control. To test this, we probed for another important costimulatory molecule, CD40, which is necessary for productive interactions between $\mathrm{T}$ and $\mathrm{B}$ cells. ${ }^{8}$ The ligation between CD40 on antigen-presenting cells such as B cells and dendritic cells and CD40 ligand expressed on T cells is known to trigger $\mathrm{T}$ cell activation. ${ }^{19}$ The density of CD $40^{+}$TILs was indeed associated with better HCC patient survival (figure 4E). We observed that CD40 is expressed on average in 54\% (range, 11-99\%) of the total CD20 ${ }^{+}$B cells within the HCC microenvironment. On the other hand, 54\% (range, $22-81 \%$ ) of $\mathrm{CD} 40^{+}$cells are $\mathrm{CD} 20^{-} \mathrm{B}$ cells, with other CD40-expressing cells including $\mathrm{S}_{100^{+}}$dendritic cells (figure 4F).

\section{Expression of CD38 on TILs correlates with longer patient survival}

Next, we probed for the expression of CD38 on TILs in HCC. CD38 is expressed on activated B cells such as germinal centre $\mathrm{B}$ cells, memory B cells, plasmablasts or plasma cells. ${ }^{20}$ It is also expressed on other immune cells such as T and NK cells upon activation $^{21}{ }^{22}$ or monocytes. $^{23}$ Interestingly, $\mathrm{CD} 27^{+} \mathrm{CD} 38^{+} \mathrm{CD} 138^{+}$plasma cells were observed within HCC tumours and in most cases near the margin of the tumours (figure 5A). The $\mathrm{CD} 38^{+} \mathrm{CD} 138^{+}$plasma cells are a rare population within the tumour with only about 9 cells $/ \mathrm{mm}^{2}$ compared with 40 cells $/ \mathrm{mm}^{2}$ of CD20 ${ }^{+}$B cells. Most of the $\mathrm{CD} 8^{+}$cells are, however, CD20 ${ }^{-}$(on average, only $0.8 \%$ (range, $0-5 \%$ ) of the entire $\mathrm{CD}^{+} 8^{+}$population is $\mathrm{CD} 38^{+} \mathrm{CD} 20^{+}$) and $\mathrm{CD} 27^{+}$(on average, 58\% (range, 30-99\%) of total $\mathrm{CD} 38^{+}$cells coexpress CD27). This indicates that half of the CD $38^{+}$TILs could potentially be activated T cells, NK cells, monocytes or plasma cells which lack CD20 expression. Indeed, flow cytometry analysis on freshly isolated TILs from tumour samples taken from patients with HCC showed that majority of the CD38 ${ }^{+}$TILs are either $\mathrm{CD} 3^{+} \mathrm{T}$ cells (average $37 \%$ ) or $\mathrm{CD}_{14}{ }^{+}$monocytes (average $29 \%$ ) (figure $5 \mathrm{~B}$ ). Plasma cells detectable as $\mathrm{CD} 38^{+} \mathrm{CD} 138^{+} \mathrm{CD} 27^{+} \mathrm{CD} 19^{-}$(average $5 \%$

A

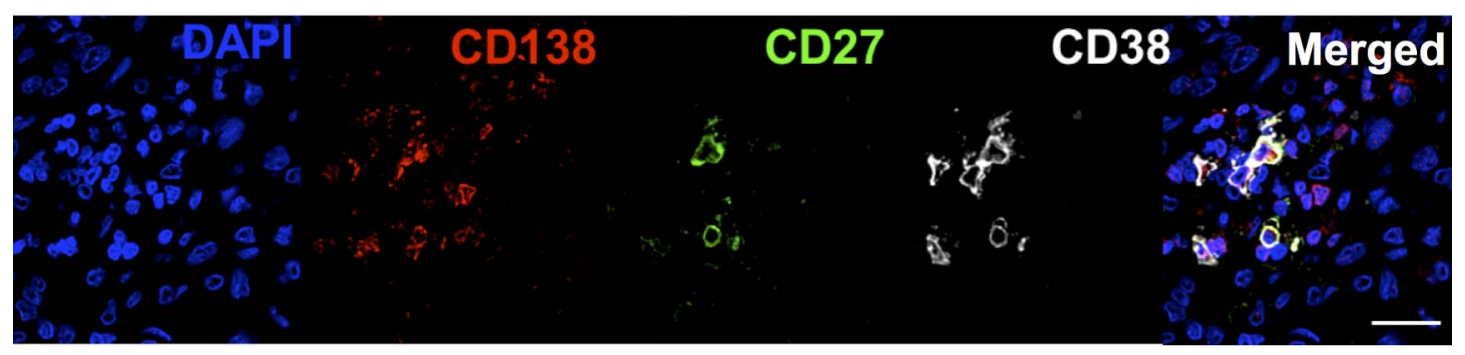

$800 x$
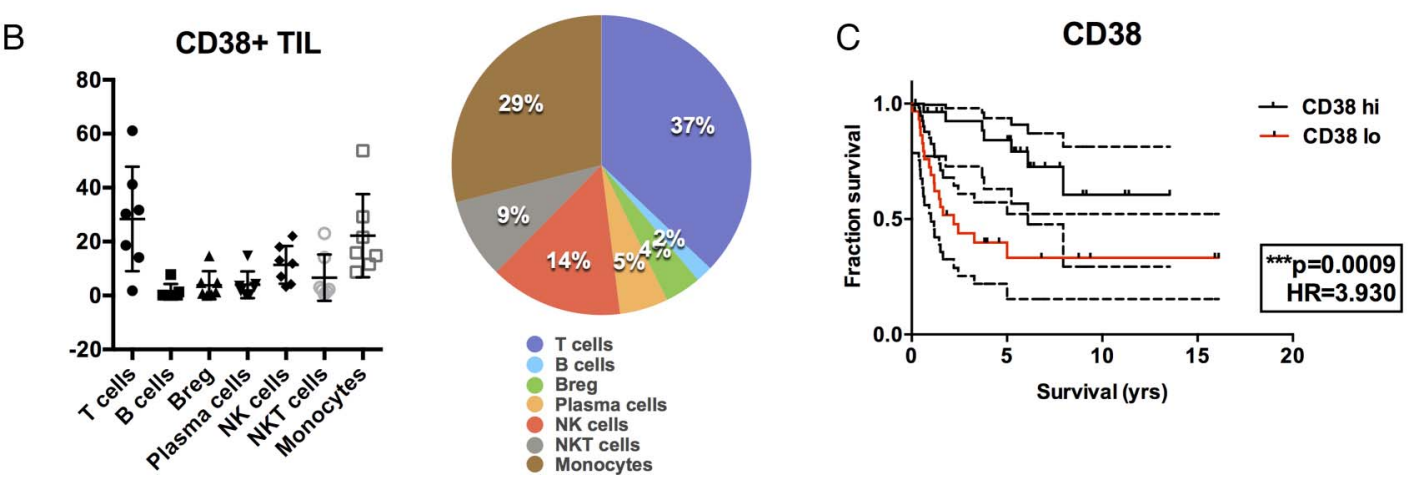

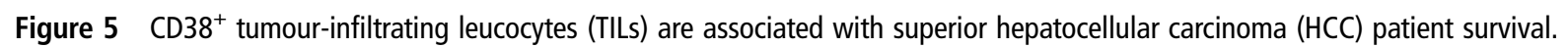

(A) Representative immunofluorescence images at 800× magnification showing DAPI (blue), CD138 (red), CD27 (green), CD38 (white) and merged image on the far right. Bar $=20 \mu \mathrm{m}$. (B) Population of $\mathrm{CD} 38^{+}$TILs isolated from freshly resected HCC specimens $(\mathrm{n}=7)$, each dot represents one tumour. Definitions: T cells $\left(C D 3^{+}\right), B$ cells $\left(C D 19^{+} C D 24^{-}\right)$, regulatory B cells (Bregs) $\left(C D 24^{+}\right.$CD19 $9^{+}$, plasma cells $\left(C D 138^{+}\right), N_{K}\left(C D 56^{+}\right), N_{K T}$ $\left(\mathrm{CD}^{+} \mathrm{CD}^{+} 6^{+}\right)$and monocytes $\left(\mathrm{CD} 14^{+}\right)$. Graph shows mean and SD. Right, pie chart showing representative distribution of $\mathrm{CD} 38^{+}$TILs based on the average percentage from seven HCC tumours. (C) Kaplan-Meier analysis graph showing that CD38 ${ }^{+}$TILs are associated with superior HCC patient survival $(n=59)$. Graphs show $p=\log$-rank test $p$ value. ${ }^{* * *} p<0.001$. NKT, natural killer T cells. 
of total $\mathrm{CD} 38^{+}$TILs) and Bregs as defined by $\mathrm{CD} 38^{+} \mathrm{CD} 24^{+} \mathrm{CD} 19^{+}$(average $4 \%$ of total CD $38^{+}$TILs) are both rare events in TILs (figure $5 \mathrm{~B}$ ). As plasma cells produce large quantities of antibodies, we also probed for human IgG expression in HCC tissues. Indeed, antibodies were shown to be bound to HCC tumour cells and costained with plasma cell marker CD138 (see online supplementary figure S5A, B). Importantly, the density of $\mathrm{CD} 8^{+}$TILs is associated with better HCC patient survival (figure 5C). Again, this indicates the activated immune microenvironment of HCC plays a critical role in superior HCC patient survival.
Depletion of $\mathrm{CD}_{2} \mathrm{O}^{+}$mature $\mathrm{B}$ cells resulted in reduced tumour control and decreased local $\mathrm{T}$ cell activation

Next, to further strengthen our claim on the important role of TIBs in HCC, we depleted the mature B cells from WT C57BL/ 6 mice using anti-mouse CD20 mAb or with isotype-matched $\mathrm{mAb}$ (Genentech) as control according to previous report. ${ }^{16}$ These mice were then transplanted with murine hepatoma cell lines Hepa1-6 on Day 16 after B cell depletion and tumour growth was monitored for another 15 days until Day 31. First of all, we established that B cells were successfully depleted from these mice even on Day 31 (figure 6A). Tumour growth was
Figure $6 \mathrm{CD}^{2} \mathrm{O}^{+} \mathrm{B}$ cell depletion reduced tumour control and decreased T cell activation. Wild-type (WT) C57BL/6 mice were transplanted with Hepa1-6 cells and tumour growth was monitored. (A) Successful B cell depletion showing less than $0.3 \%$ of $B$ cells present in the spleens of the mice at Day 31 after injection with anti-mouse CD20 mAb compared with more than $30 \%$ of $B$ cells in those injected with isotype control mouse IgG2a antibody. (B) Tumour growth was enhanced in B cell-depleted mice compared with control mice. $n=4-8$ tumours in each group. (C) Left, representative images showing larger tumours harvested from B cell-depleted mice versus control mice on Day 31 . Right, graph showing bigger tumours by weight $(\mathrm{g})$ harvested from B cell-depleted mice versus control mice. Percentage (\%) of (D) IFN- $\gamma$ and granzyme B (GZB). (E) CD69 and (F) PD-1 on $\mathrm{CD}^{+} \mathrm{T}, \mathrm{CD} 8^{+} \mathrm{T}$ and NK1.1 ${ }^{+}$ NK cells isolated from tumours harvest from $B$ cell-depleted mice versus control mice. All graphs show ${ }^{*} p<0.05$ from unpaired Student's t test except (B) $p<0.0001$ from one-way ANOVA test.
A

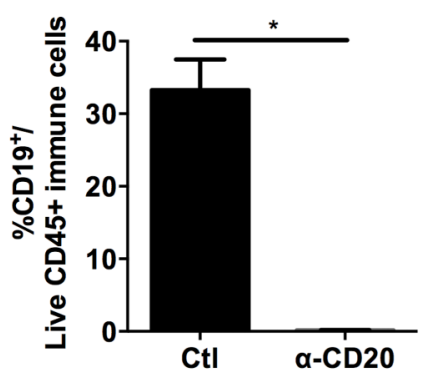

C

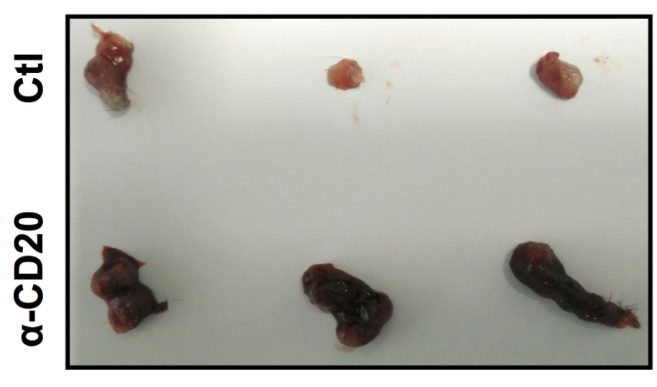

D

$\% \mathrm{IFN} \gamma$

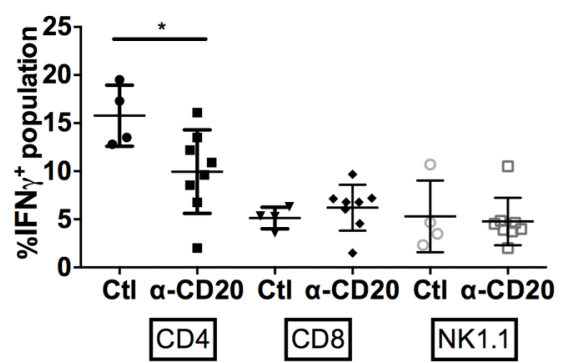

E

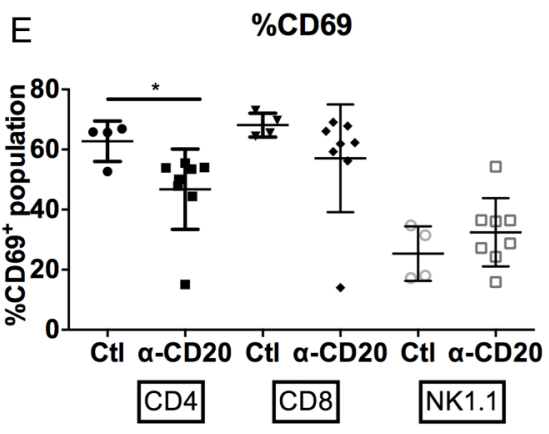

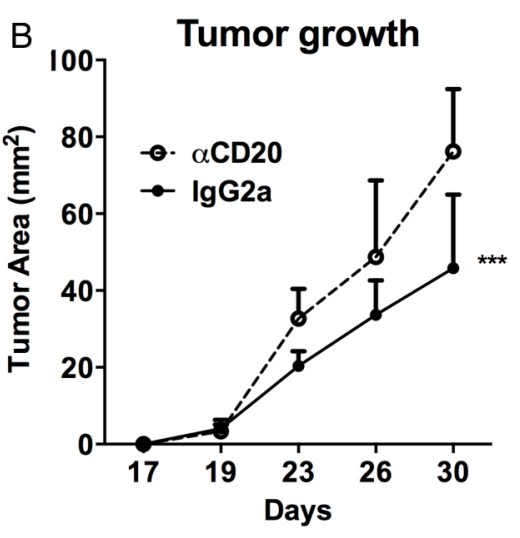

Final tumor weight D31

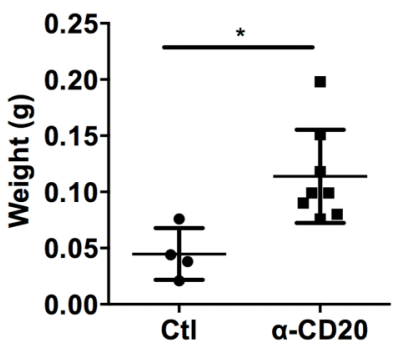

$\%$ GZB

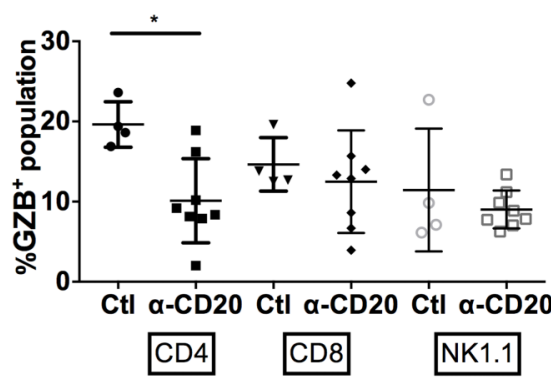

$\mathrm{F} \quad$ \%PD-1

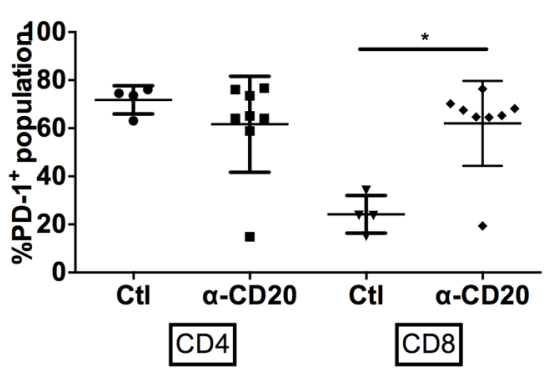


significantly enhanced in mice depleted of B cells (figure 6B) resulting in larger tumour size at harvest on Day 31 (figure 6C). We observed no significant difference in tumour-infiltrating $\mathrm{CD}^{+} \mathrm{T}$ cells, but a corresponding reduction of $\mathrm{CD} 20^{+} \mathrm{B}$ cells in tumours from control undepleted mice versus CD20-depleted mice (data not shown). To support our above hypothesis that TIBs play an important role in local $\mathrm{T}$ cell activation, we then examined the T cell activation status from TILs. Indeed, $\mathrm{CD} 4^{+}$ T cell activation was reduced with $B$ cell depletion shown by the reduced expression of IFN- $\gamma$, GZB (figure 6D) and CD69, an early activation marker (figure $6 \mathrm{E}$ ). Notably, we do not observe a significant difference in $\mathrm{CD} 8^{+} \mathrm{T}$ cell activation in this current model. However, the expression of PD-1, an inhibitory receptor marker, was enhanced on $\mathrm{CD} 8^{+}$TILs upon $\mathrm{B}$ cell depletion (figure $6 \mathrm{~F}$ ). This indicates that the activation of $\mathrm{CD}^{+}{ }^{+} \mathrm{T}$ cells was also influenced by $\mathrm{CD} 20^{+} \mathrm{B}$ cells. In conclusion, we demonstrated TIBs play an important role in tumour control via $\mathrm{T}$ cell activation.

\section{DISCUSSION}

We demonstrated that densities of both $\mathrm{T}$ and $\mathrm{B}$ cells are associated with HCC patient survival, and that they are in close proximity and seemingly at cell-to-cell contact with one another, most likely an indication of a functional interaction between them. To support this hypothesis, we found that the density of TIBs correlates with the number and activation status of both T and NK cells and coincides with reduced tumour cell viability. Using a mouse model transplanted with murine hepatoma cells, we demonstrated that the depletion of $\mathrm{B}$ cells resulted in an enhanced tumour growth and reduced local $\mathrm{T}$ cell activation. We conclude that the interaction between $\mathrm{B}$ and $\mathrm{T}$ cells is an important event leading to their activation and hence contributing to better tumour control in HCC.

Our current study partially contradicts an earlier report showing that circulating Bregs defined as $\mathrm{CD} 19^{+} \mathrm{CD} 24^{\mathrm{hi}} \mathrm{CD} 38^{\mathrm{hi}}$ population promoted HCC progression via the CD40/CD40L signalling pathway. ${ }^{6}$ Instead, we found that Breg cells represent a minor population in TILs counting for less than $5 \%$ of the CD $38^{+}$TILs in fresh tumour samples. It may also be difficult to directly compare our study, based on TIBs, with Shao's report on circulating Bregs. Rather, our findings support and extend several other studies consistent with antitumour activity of intratumoral B cells. ${ }^{524}{ }^{25}$ For instance, Schneider $e t$ al $l^{5}$ reported that adaptive immunity, in particular $\mathrm{T}$ and $\mathrm{B}$ cells, is critical for the suppression of HCC progression. On the other hand, Nielson et al described CD20 ${ }^{+}$TIBs with an atypical CD27 memory phenotype to be correlated with better prognosis in ovarian cancer. ${ }^{25}$ Both studies highlighted the importance of $\mathrm{T}$ and $\mathrm{B}$ cell interaction in triggering functional adaptive immune response.

The role of costimulatory molecules CD27/CD70 in tumour control has been widely reported. ${ }^{26-28}$ Previous studies showed that $\mathrm{CD} 27$ is expressed on most $\mathrm{T}$ cells, including naive $\mathrm{T}$ cells, and its expression is increased upon Tcell activation, but downregulated as T cells differentiate towards effector phenotypes. ${ }^{29}$ However, it has also been shown that in secondary lymphoid organs, CD27 expression is retained on central memory T cells. ${ }^{30}$ Its expression on B cells, on the other hand, is usually detected on activated ${ }^{18}$ and memory B cells. ${ }^{31} 32 \mathrm{CD} 27$ was reported to play an important role in T cell expansion and survival as well as in B cell activation and antibodies production. ${ }^{26}$ The expression of CD27 on intratumoral B cells could therefore be indicative of their activation and active local immune response within the tumour microenvironment. It was previously shown that the population of $\mathrm{CD} 19^{+} \mathrm{CD} 27^{+}$B cells was decreased in HCC. ${ }^{33}$ This could indicate a negative feedback mechanism during tumour progression. In the current study, we demonstrated that both $\mathrm{CD} 27^{+}$T cells and $\mathrm{CD} 27^{+} \mathrm{B}$ cells are present in the tumour of patients with HCC and that their densities are associated with longer patient survival. Furthermore, we demonstrated the presence of $\mathrm{CD} 27^{+} \mathrm{CD} 38^{+} \mathrm{CD} 138^{+}$plasma cells in the tumour microenvironment. CD $38^{+}$TILs, which could be activated T and NK cells, ${ }^{21} 22$ germinal centre B cells, memory B cells, plasmablasts, plasma cells ${ }^{34}$ or monocytes, ${ }^{23}$ were also shown to be associated with better patient survival.

This study also showed a correlation of $\mathrm{CD} 40^{+}$cells with better HCC patient survival. CD40 is an important costimulatory molecule expressed on $\mathrm{B}$ cells that upon ligation with CD40 ligand leads to activation of both T and B cells. ${ }^{35}$ CD40 agonists have been tested as cancer immunotherapies in recent years. ${ }^{36}$ It was previously reported that CD40 ligand-activated B cells transfected with tumour total RNA isolated from HCC cells were able to induce cytotoxic $\mathrm{T}$ cell response ex vivo. ${ }^{26}$ The current study is the most comprehensive study of costimulatory molecules in HCC, since it involves analysis of the largest number of HCC cases and largest number of costimulatory molecules indicative of $\mathrm{T}$ and $\mathrm{B}$ cell interaction thus far.

In the mouse model transplanted with Hepa1-6 cells, we clearly demonstrated the role of TIBs in tumour control whereby their depletion leads to an enhanced tumour growth and reduced local $\mathrm{T}$ cell activation. The effect on T cell activation was mainly observed on $\mathrm{CD}^{+}{ }^{+} \mathrm{T}$ cells where the expression of IFN- $\gamma$, GZB and CD69 was significantly decreased. On $\mathrm{CD}^{+}{ }^{+}$T cells, however, PD-1 was significantly increased when B cells were depleted in these mice. In this particular case, we refer to PD-1 marker as inhibitory receptor rather than an exhaustion marker since the expression of IFN- $\gamma$ and GZB from $\mathrm{CD}^{+} \mathrm{T}$ cells was not significantly reduced in B cell-depleted animals. ${ }^{37}$ This is somehow in contrast to our observation in human HCCs showing that B and T cell interaction leads to $\mathrm{CD}^{+}{ }^{+} \mathrm{T}$ cell activation marked by the expression of IFN- $\gamma$ and GZB. We believe that this difference is due to the chronic effect of $\mathrm{B}$ cells, which interact first with $\mathrm{CD}^{+}{ }^{+} \mathrm{T}$ cells leading to the enhanced local immune response and eventually to the activation of $\mathrm{CD}^{+}{ }^{+} \mathrm{T}$ cells. ${ }^{38-40}$ This explanation is consistent with the fact that animal studies were performed within 15 days after tumour transplantation, while the human HCC samples were examined years after the tumours were established.

In conclusion, this study provides comprehensive data from patients with HCC, indicating a critical role of $\mathrm{T}$ and $\mathrm{B}$ cell interaction in cancer progression. Our findings warrant further investigations for the design of future immunotherapies leading to local immune response and improved patient survival.

\footnotetext{
Author affiliations

${ }^{1}$ Singapore Immunology Network (SIgN), Agency for Science, Technology and Research $\left(A^{*}\right.$ STAR), Biopolis, Singapore

${ }^{2}$ Institute of Molecular and Cell Biology (IMCB), A*STAR, Biopolis, Singapore ${ }^{3}$ Department of Pathology, Singapore General Hospital, Singapore, Singapore ${ }^{4}$ SingHealth Translational Immunology and Inflammation Centre (STIIC), Singapore Health Services Pte Ltd, Singapore, Singapore

${ }^{5}$ Institute of Surgical Pathology, University Hospital of Zurich, Zurich, Switzerland

${ }^{6}$ National Cancer Centre, Singapore, Singapore

${ }^{7}$ Singapore General Hospital, Singapore, Singapore

${ }^{8}$ Division of Chronic Inflammation and Cancer, German Cancer Research Center (DKFZ), Heidelberg, Germany

${ }^{9}$ Institute of Virology, Technical University München/Helmholtz Zentrum München, Germany

${ }^{10}$ Department of Pathology, The University of Hong Kong, Queen Mary Hospital, Hong Kong, Hong Kong
} 
${ }^{11}$ State Key Laboratory for Liver Research, The University of Hong Kong, Hong Kong, Hong Kong

${ }^{12}$ Institut de Recherches Internationales Servier, Suresnes, France

${ }^{13}$ Duke-NUS Graduate Medical School, Singapore, Singapore

Acknowledgements We wish to thank Dr Chai Ling Pang for her help in IHC staining. We thank Sarah Novack from Servier, France, for manuscript editing. We also thank Genentech for their kind gift of the anti-mouse CD20 mAb (clone 5D2) and the isotype-matched control lgG2a mAb as well as Dr Lakshmi Ramakrishna and Professor Salvatore Albani for preparing the Material Transfer Agreement. This work was mainly supported by the Biomedical Research Council of A*STAR (Agency for Science, Technology and Research), Singapore, and Ministry of Health Industrial Alignment Fund (MOH IAF) Category 2 grant. Dr Mathias Heikenwalder's contribution was supported by an European Research Council (ERC) starting grant (Liver Cancer Mechanisms), the Stiftung für Experimentelle Biomedizin (Hans-Peter Hofschenider Stiftung), the Helmholtz Alliance Pre-clinical Cancer Center (PCCC), the SFB TR 36 and the Helmoltz-Zentrum.

Contributors MG, AT: performed most of the IHC stainings and quantifications. ZH: performed the animal work for figure 6. JY: performed the Opal staining. CJL: assisted in animal work and Opal staining. JC: biostatistician, performed univariate and multivariate analyses. KHL: pathologist, Singapore. AW: pathologist, Zurich. PC, AC, LLPJO: surgeons providing fresh HCC samples. HCT, MH, IOLN: oncologists from Singapore, Zurich and Hong Kong, respectively, involved in patient recruitment and sample collections. AN, J-PA: supervising the project. QC: supervisor for animal work. VC: main supervisor for the entire project.

Funding National Medical Research Council (NMRC), Singapore, Ministry of Health $(\mathrm{MOH})$, Industry Alignment Fund, Biomedical Research Council (BMRC), Singapore.

Competing interests None declared.

Patient consent Obtained.

Ethics approval Centralised Institutional Review Board (CIRB), SingHealth.

Provenance and peer review Not commissioned; externally peer reviewed.

Open Access This is an Open Access article distributed in accordance with the Creative Commons Attribution Non Commercial (CC BY-NC 4.0) license, which permits others to distribute, remix, adapt, build upon this work non-commercially, and license their derivative works on different terms, provided the original work is properly cited and the use is non-commercial. See: http://creativecommons.org/ licenses/by-nc/4.0/

\section{REFERENCES}

1 Ferlay J, Soerjomataram I, Dikshit R, et al. Cancer incidence and mortality worldwide: sources, methods and major patterns in GLOBOCAN 2012. Int I Cancer 2015;136:E359-86.

2 Nikolaou K, Sarris M, Talianidis I. Molecular pathways: the complex roles of inflammation pathways in the development and treatment of liver cancer. Clin Cancer Res 2013;19:2810-16.

3 Pagès F, Galon J, Dieu-Nosjean MC, et al. Immune infiltration in human tumors: a prognostic factor that should not be ignored. Oncogene 2010;29:1093-102.

4 Jochems C, Schlom J. Tumor-infiltrating immune cells and prognosis: the potential link between conventional cancer therapy and immunity. Exp Biol Med (Maywood) 2011;236:567-79.

5 Schneider C, Teufel A, Yevsa T, et al. Adaptive immunity suppresses formation and progression of diethylnitrosamine-induced liver cancer. Gut 2012;61:1733-43.

6 Balkwill F, Montfort A, Capasso M. B regulatory cells in cancer. Trends Immunol 2013;34:169-73

7 Shao Y, Lo CM, Ling CC, et al. Regulatory B cells accelerate hepatocellular carcinoma progression via CD40/CD154 signaling pathway. Cancer Lett 2014;355:264-72.

8 Driessens G, Kline J, Gajewski TF. Costimulatory and coinhibitory receptors in anti-tumor immunity. Immunol Rev 2009;229:126-44.

9 Peggs KS, Quezada SA, Allison JP. Cancer immunotherapy: co-stimulatory agonists and co-inhibitory antagonists. Clin Exp Immunol 2009:157:9-19.

10 Pauken KE, Wherry EJ. TIGIT and CD226: tipping the balance between costimulatory and coinhibitory molecules to augment the cancer immunotherapy toolkit. Cancer Cell 2014;26:785-7.

11 Chew V, Chen J, Lee D, et al. Chemokine-driven lymphocyte infiltration: an early intratumoural event determining long-term survival in resectable hepatocellular carcinoma. Gut 2012;61:427-38
12 Abel EJ, Bauman TM, Weiker M, et al. Analysis and validation of tissue biomarkers for renal cell carcinoma using automated high-throughput evaluation of protein expression. Hum Pathol 2014;45:1092-9.

13 Stack EC, Wang C, Roman KA, et al. Multiplexed immunohistochemistry, imaging, and quantitation: a review, with an assessment of Tyramide signal amplification, multispectral imaging and multiplex analysis. Methods 2014;70:46-58.

14 Lovisa S, LeBleu VS, Tampe B, et al. Epithelial-to-mesenchymal transition induces cell cycle arrest and parenchymal damage in renal fibrosis. Nat Med 2015:21:998-1009.

15 Chew $\mathrm{V}$, Tow $\mathrm{C}$, Teo $\mathrm{M}$, et al. Inflammatory tumour microenvironment is associated with superior survival in hepatocellular carcinoma patients. J Hepatol 2010:52:370-9.

16 Montalvao F, Garcia Z, Celli S, et al. The mechanism of anti-CD20-mediated B cell depletion revealed by intravital imaging. J Clin Invest 2013;123:5098-103.

17 Kobata T, Jacquot S, Kozlowski S, et al. CD27-CD70 interactions regulate B-cell activation by T cells. Proc Natl Acad Sci USA 1995;92:11249-53.

18 Borst J, Hendriks J, Xiao Y. CD27 and CD70 in T cell and B cell activation. Cur Opin Immunol 2005;17:275-81.

19 Hernandez MG, Shen L, Rock KL. CD40-CD40 ligand interaction between dendritic cells and CD8+ T cells is needed to stimulate maximal $T$ cell responses in the absence of CD4+ T cell help. J Immunol 2007;178:2844-52.

20 Kaminski DA, Wei C, Qian Y, et al. Advances in human B cell phenotypic profiling. Front Immunol 2012:3:302.

21 Mallone R, Funaro A, Zubiaur $M$, et al. Signaling through CD38 induces NK cell activation. Int Immunol 2001:13:397-409.

22 Sandoval-Montes C, Santos-Argumedo L. CD38 is expressed selectively during the activation of a subset of mature $T$ cells with reduced proliferation but improved potential to produce cytokines. J Leukoc Biol 2005;77:513-21.

23 Musso T, Deaglio S, Franco L, et al. CD38 expression and functional activities are up-regulated by IFN-gamma on human monocytes and monocytic cell lines. J Leukoc Biol 2001;69:605-12.

24 Nelson BH. CD20+ B cells: the other tumor-infiltrating lymphocytes. J Immunol 2010;185:4977-82

25 Nielsen JS, Sahota RA, Milne K, et al. CD20+ tumor-infiltrating lymphocytes have an atypical CD27- memory phenotype and together with CD8+ T cells promote favorable prognosis in ovarian cancer. Clin Cancer Res 2012;18:3281-92.

26 Denoeud J, Moser M. Role of CD27/CD70 pathway of activation in immunity and tolerance. J Leukoc Biol 2011:89:195-203.

27 He L-Z, Prostak N, Thomas LJ, et al. Agonist anti-human CD27 monoclonal antibody induces $T$ cell activation and tumor immunity in human CD27-transgenic mice. J Immunol 2013;191:4174-83.

28 Roberts DJ, Franklin NA, Kingeter LM, et al. Control of established melanoma by CD27 stimulation is associated with enhanced effector function and persistence, and reduced PD-1 expression of tumor infiltrating CD8(+) T cells. J Immunother 2010;33:769-79.

29 Nolte MA, van Olffen RW, van Gisbergen $\mathrm{KP}$, et al. Timing and tuning of CD27-CD70 interactions: the impact of signal strength in setting the balance between adaptive responses and immunopathology. Immunol Rev 2009:229:216-31.

30 Wherry EJ, Teichgräber V, Becker TC, et al. Lineage relationship and protective immunity of memory CD8T cell subsets. Nat Immunol 2003:4:225-34.

31 Wei C, Jung J, Sanz I. OMIP-003: phenotypic analysis of human memory B cells. Cytometry A 2011;79:894-6.

32 Kurosaki T, Kometani K, Ise W. Memory B cells. Nat Rev Immunol 2015;15:149-59

33 Wang XD, Wang L, Ji FJ, et al. Decreased CD27 on B lymphocytes in patients with primary hepatocellular carcinoma. J Int Med Res 2012;40:307-16.

34 Pittner BT, Shanafelt TD, Kay NE, et al. CD38 expression levels in chronic lymphocytic leukemia B cells are associated with activation marker expression and differential responses to interferon stimulation. Leukemia 2005;19:2264-72.

35 Grewal IS, Flavell RA. The role of CD40 ligand in costimulation and T-cell activation. Immunological reviews 1996;153:85-106.

36 Khong A, Nelson DJ, Nowak AK, et al. The use of agonistic anti-CD40 therapy in treatments for cancer. Int Rev Immunol 2012:31:246-66.

37 Fuertes Marraco SA, Neubert NJ, Verdeil G, et al. Inhibitory receptors beyond T cell exhaustion. Front Immunol 2015;6:310.

38 Zhang S, Zhang $\mathrm{H}$, Zhao J. The role of CD4T cell help for CD8 CTL activation. Biochem Biophys Res Commun 2009;384:405-8.

39 Phares TW, Stohlman SA, Hwang M, et al. CD4T cells promote CD8T cell immunity at the priming and effector site during viral encephalitis. J Virol 2012;86: 2416-27.

40 Castiglioni P, Gerloni M, Cortez-Gonzalez $X$, et al. CD8T cell priming by B lymphocytes is CD4 help dependent. Eur J Immunol 2005;35:1360-70. 